\title{
Investigation of the status of occupational radiation protection in Malawian hospitals
}

\author{
Getrude Chinangwa ${ }^{1}$, Joseph Kwabena Amoako ${ }^{2}$, John Justice Fletcher ${ }^{3}$ \\ 1. University of Ghana, Graduate School of Nuclear and Allied Sciences (SNAS) \\ 2. Radiation Protection Institute (RPI), Ghana Atomic Energy Commission (GAEC) \\ 3. University of Ghana, Graduate School of Nuclear and Allied Sciences (SNAS), Department of Nuclear \\ Sciences and Applications
}

Correspondence to: Getrude Chinangwa; chinangwag@gmail.com

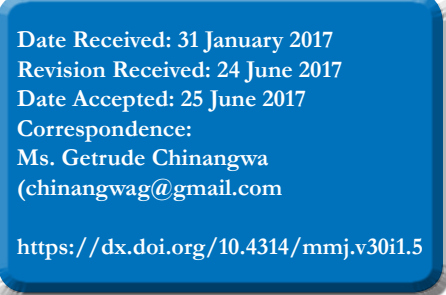

\begin{abstract}
Background
Abstract

The main objective of this study was to explore the occupational radiation protection program in three hospitals in Malawi and discover how radiation protection measures for workers are being implemented in their radiology departments.

Method

A questionnaire was administered to heads of X-ray departments for Kamuzu Central Hospital, Bwaila Hospital and Mtengo wa Nthenga Hospital to investigate occupational radiation protection practices in their departments.

Results

The study discovered that hospitals lack radiation protection programs which covers a number of critical issues including quality assurance and personnel dose monitoring.

Conclusion

The implementation of basic elements of occupational radiation protection in Malawian hospitals is inadequate.
\end{abstract}

\section{Introduction}

Diagnostic radiology is the major practice involving occupational exposure to ionizing radiation in Malawi. The term 'occupational exposure' refers to the exposure incurred by a worker which is attributable to the worker's occupation and it is received or committed during a period of work ${ }^{1}$. The International Atomic Energy Agency (IAEA) Basic Safety Standards ${ }^{2}$ requires that occupational radiation protection programme be established and managed in coordination with other health and safety disciplines at every workplace concerned with ionizing radiation. Malawi became a member state of IAEA in 2006 and developed the Atomic Energy Act in 2011 and Atomic Energy Regulations in 2012 ${ }^{3}$. By becoming a member state of IAEA, it entails that the Malawi Government pledged its commitment to applying and implementing the Basic Safety Standards in all facilities and practices involving the use of ionizing radiation including in hospitals. It should be noted that radiation protection is one of the many issues that must be addressed in order to protect the worker's overall health and safety.

Basically, exposure to ionising radiation has two main effects to human beings. These are: deterministic effects and stochastic effects ${ }^{4}$. Deterministic effects are those effects for which generally a threshold level of dose exists above which the severity of the effect is greater for a higher dose. Examples include: acute radiation syndrome (ARS), skin burns, sterility and cataract. These effects are mainly associated with exposure to high radiation doses for a short time (acute exposure). On the other hand, stochastic effects are the effects, generally occurring without a threshold level of dose, but their probability of occurrence is proportional to the dose and their severity is independent of the dose. Radiation induced cancer and some hereditary effects are main examples of stochastic effects. These effects are associated with exposure to low radiation doses for consistent long time (chronic exposure).

For every practice that involves the use of ionizing radiation, it is important for protection to be optimized. Optimization simply means the process of making sure that the number of individuals subject to exposure, the likelihood of exposure and the magnitude of exposure are kept as low as reasonably achievable (ALARA) ${ }^{5}$. Optimization is key to achieving the aim of radiation protection which is to prevent deterministic effects and reduce the probability of stochastic effects. ALARA principle is achieved in three ways and these are: reducing the time of exposure, being far from the radiation source (i.e. observing distance), and shielding the radiation source or the person subject to exposure.

This study was therefore designed to investigate this aspect of radiation protection for workers in Malawian hospitals based on the following research questions:

- Are radiation protection measures being practiced in radiology departments of hospitals in Malawi?

- What mechanisms are hospitals employing to optimize radiation safety?

The relevance of this study was that it contributed to useful baseline information for Malawi particularly in the field of radiation protection, which has not yet advanced in the country. The research findings would be a basis for other follow up studies.

\section{Materials And Methods}

A questionnaire was administered to three X-ray departments of three hospitals (Kamuzu Central Hospital, Bwaila Hospital and Mtengo wa Nthenga Hospital). These hospitals were purposively sampled based on the three levels of health care service delivery in Malawi (i.e. regional level, district level and community level). Kamuzu Central Hospital was chosen as 
a regional hospital, Bwaila Hospital as a district hospital and Mtengo wa Nthenga Hospital as a community hospital.

The purpose was to obtain information about radiation protection of workers in these departments. Specifically, the questionnaire was meant to explore the existence of the radiation protection program in the facility by assessing the presence of different elements that comprise the program. Ideally, Occupational Radiation Programs involve the following elements among others ${ }^{6}$ :

- Assigning responsibilities

- Quality assurance and control

- Personnel Dosimetry Program

- Area or workplace monitoring

- Record Keeping and Reporting

- Radiation Safety Training

- Emergency preparedness and response

- Personal protective equipment

\section{Workload Calculation}

Workload is simply the radiation output of the machine per week ${ }^{7}$. It is expressed in $\mathrm{mA}$-minutes per week. It gives an indication of the radiation quantity being produced by the X-ray machine in a week which will ultimately have an effect on the exposure of patients as well as workers. High workload entails increased exposure. Workload of the X-ray machines was evaluated using the formula below:

$\mathrm{W}=\mathrm{R} \times \mathrm{D} \times \mathrm{E}$

where: $\mathrm{W}=$ workload (in $\mathrm{mA}$ minutes per week); $\mathrm{R}=$ number of radiographs per day; $\mathrm{D}=$ number of days of operation per week; $\mathrm{E}=$ exposure (in $\mathrm{mA}$ minutes)

\section{Results And Discussion}

As shown in Table 1, it was discovered that crucial aspects of an effective radiation protection program (such as the radiation safety committees, quality assurance program and personnel monitoring program) were not existent in these facilities. Workers in these facilities require training in radiation protection, more especially those who were appointed as Radiation Protection Officers (RPOs). The absence of quality assurance program tarries with the findings in Chinamale's study in $2010^{8}$. Due to lack of quality control equipment, the operators are unable to perform the quality control tests which help to ensure that the machines are operating properly according to the image quality and radiation protection requirements. This is the common scenario even in other African countries. In other countries where the regulatory authorities are functional, the quality control tests are performed by regulatory authority officials during their regular inspections to the facilities. In that way, the regulatory authorities act as both watchdogs as well as backup in making sure that the operational and protection standards are not compromised. However, this is a big challenge in Malawi, where the regulatory authority has not yet been established. As such the quality control tests are not being performed at all.

It was also discovered that safety assessments are not conducted at the installation stage of the machines, during operation, maintenance and also at decommissioning.

Table 1: Status of occupational radiation protection

\section{measures in hospitals}

\begin{tabular}{|c|c|c|c|c|}
\hline Element & $\begin{array}{l}\text { Mtengo wa } \\
\text { Nthenga }\end{array}$ & Bwaila & $\mathbf{K C H}$ & Remarks \\
\hline Number of X-ray machines & 1 & 1 & $6^{*}$ & *with $1 \mathrm{CT}$ \\
\hline Number of workers & 1 & 3 & $17 *$ & $\begin{array}{l}\text { *Including } 1 \\
\text { radiologist }\end{array}$ \\
\hline $\begin{array}{l}\text { Average number of patients } \\
\text { per day }\end{array}$ & 10 & 150 & $15^{*}$ & $\begin{array}{l}* \text { For CT } \\
\text { scanning }\end{array}$ \\
\hline $\begin{array}{l}\text { Presence of qualified and } \\
\text { experienced personnel }\end{array}$ & Yes & Yes & Yes & \\
\hline $\begin{array}{l}\text { Presence of radiation } \\
\text { protection officer }\end{array}$ & Yes* & No & Yes* & $\begin{array}{l}* \text { But not } \\
\text { formally trained } \\
\text { in radiation } \\
\text { protection }\end{array}$ \\
\hline $\begin{array}{l}\text { *Number of personnel } \\
\text { trained in Radiation } \\
\text { Protection }\end{array}$ & 0 & 0 & 2 & $\begin{array}{l}\text { *Special training } \\
\text { in radiation } \\
\text { safety }\end{array}$ \\
\hline $\begin{array}{l}\text { Presence of radiation safety } \\
\text { committee }\end{array}$ & No & No & No & \\
\hline $\begin{array}{l}\text { Presence of quality } \\
\text { assurance program }\end{array}$ & No & No & No & \\
\hline $\begin{array}{l}\text { Presence of personnel } \\
\text { monitoring program }\end{array}$ & No & No & No & \\
\hline $\begin{array}{l}\text { Routine workplace radiation } \\
\text { surveys }\end{array}$ & No & No & No & \\
\hline $\begin{array}{l}\text { Presence of protective wear } \\
\text { (lead aprons) }\end{array}$ & Yes & Yes & Yes & But rarely used \\
\hline Presence of warning lights & No & No & Yes* & $*$ One functional \\
\hline $\begin{array}{l}\text { Presence of radiation } \\
\text { symbols }\end{array}$ & No & No & Yes & \\
\hline $\begin{array}{l}\text { Display of operating } \\
\text { procedures }\end{array}$ & Yes & No & Yes & \\
\hline
\end{tabular}

The radiation surveys around the workplace are not performed, and there is no program for monitoring the exposure of individual workers. One facility $(\mathrm{KCH})$ reported to have engaged South Africa Bureau of Standards (SABS) as a personnel monitoring service provider at one time using TLDs. However, SABS stopped providing the service due to the client's failure to pay the bills for some time.

These discovered inadequacies confirm the challenges of radiation safety present in most African countries stipulated in the AFROSAFE Implementation Tool Matrix?. Other challenges stipulated in the Matrix include: inadequate awareness of radiology safety policies among occupationally exposed workers, inadequate knowledge, poor attitude and practice in radiation safety, and financial constraints for quality assurance programs.

\section{Workload}

Table 2 shows the weekly workload of machines in $\mathrm{mA}$.min based on the given factors for the study facilities. According to workload formula given in the methodology section above, the parameters were multiplied together to get total workload. 
Table 2: Workload of the Facilities

\begin{tabular}{|l|l|l|l|}
\hline Parameters & Mtengo wa Nthenga & Bwaila & KCH \\
& Hospital & Hospital & \\
\hline Average mAs/day & 15 & 15 & 478 \\
\hline Average \# of films/patients & 3 & 3 & 1 \\
\hline Average \# of slices/patients & - & - & 278 \\
\hline Average \# of patients/day & 10 & 150 & 15 \\
\hline \# of working days/week & 5 & 5 & 5 \\
\hline Time conversion factor & 0.01667 & 0.01667 & 0.01667 \\
\hline $\begin{array}{l}\text { Total Workload (mA.min/ } \\
\text { week) }\end{array}$ & $\mathbf{3 8}$ & $\mathbf{5 6 3}$ & $\mathbf{1 6 6 , 1 3 8}$ \\
\hline
\end{tabular}

CT Scanner's workload at $\mathrm{KCH}$ was higher than that for conventional radiography machines in the other two facilities. According to literature, CT machines generally have high workload because scanning usually involves high exposure parameters $(\mathrm{kVp} \text { and } \mathrm{mAs})^{6}$. Machines with high workload require effective shielding to attenuate high levels of scattered radiation associated ${ }^{10}$. It is therefore important for the hospitals to have the radiation safety committees and quality assurance program which will regularly confirm the quality and effectiveness of the ALARA principle. Bwaila's high workload was due to high number of patients while Mtengo wa Nthenga had low number of patients visiting the $\mathrm{X}$-ray department during the data collection period.

\section{Conclusion}

There is lack of implementation of basic elements of occupational radiation protection which is mainly as a result of the absence of the regulatory authority in the country as well as limitation of resources in the facilities. The study recommends radiographers' training in radiation protection, establishment of a regulatory authority in the country, consistent dose assessment, quality control tests and structural shielding assessment in these and probably all the diagnostic facilities in Malawi. Observing radiation safety measures in radiological facilities will ultimately contribute to the achievement of United Nations Sustainable Goal number three (i.e. good health and well-being) as well as number eight (i.e. decent work and economic growth).

\section{Acknowledgements}

The support received from the following institutions is very much appreciated: International Atomic Energy Agency, Department of Radiography in the Ministry of Health; National Health Sciences Research Committee; Management and Staff of Kamuzu Central Hospital, Bwaila Hospital and Mtengo wa Nthenga Hospital; Environmental Affairs Department, and Radiation Protection Institute of Ghana Atomic Energy Commission.

\section{References}

1.International Atomic Energy Agency. Occupational Radiation Protection: Protecting Workers Against Exposure to Ionizing Radiation. Proceedings of an International Conference; 2002 Aug 26-30; Geneva. Vienna; 2003.

2.International Atomic Energy Agency. Radiation Protection and Safety of Radiation Sources: International Basic Safety Standards (BSS), General Safety Requirements Part 3 No. GSR Part 3; Vienna; 2014.

3.Malawi Government. Atomic Energy Act; 2011.

4.International Atomic Energy Agency. Radiation Protection Distance Learning Project, Module 1.6 - Biological Effects of Exposure to Ionizing Radiation (Preprint), Available from www.iaea.org.

5.The International Commission on Radiological Protection. General Principles for the Radiation Protection of Workers. ICRP Publication 75; 1997.

6. International Atomic Energy Agency. Radiation Oncology Physics: A Handbook for Teachers and Students; Vienna; 2005.

7.National Council on Radiation Protection and Measurements. Structural Shielding Design for Medical X-ray Imaging Facilities, NCRP Report No. 147, 2004.

8. Chinamale, HM. An Investigation into the Status of Quality Assurance and Quality Control Measures in Diagnostic X-ray Departments in Malawi; 2010.

9.AFROSAFE $\mathrm{RAD}_{\text {- }}$ Championing Radiation Safety; Implementation Tool Matrix; 2015-2018.

10.The British Institute of Radiology. Radiation Shielding for Diagnostic X-rays, Report of a joint BIR/IPEM working party; 2000. 